\title{
EDITORIAL HIDUP DI USIA LANJUT TETAP SEHAT, AKTIF, DAN PRODUKTIF
}

Diterima: 27-07-2018 D Disetujui: 19-20-2018

http://dx.doi.org/10.21460/bikdw.v3i2.129

Tejo Jayadi

Fakultas Kedokteran Unviersitas Kristen Duta Wacana Yogyakarta

Email: tejo_jayadi@staff.ukdw.ac.id

Berdasarkan Undang-Undang No. 13 Tahun 1998, lanjut usia (lansia) adalah seorang yang mencapai usia 60 tahun ke atas. Proyeksi presentase penduduk lansia di Indonesia dan di dunia berdasarkan Pusat Data dan Informasi Kementrian Kesehatan RI meningkat dari 8,9\% dan 13,4\% di tahun 2013, menjadi $21,4 \%$ dan $25,3 \%$ di tahun 2050 dan menjadi $41 \%$ dan $35 \%$ di tahun 2100 . Sebaran penduduk lansia di Indonesia menurut provinsi di tahun 2012, presentasi tertinggi di Provinsi DI Yogyakarta (13.04\%), kemudian Jawa Timur $(10,40 \%)$ dan Jawa Tengah (10,34\%). Penduduk lansia dibandingkan penduduk muda memiliki pergeseran jenis penyakit dari penyakit menular (communicable diseases) menjadi penyakit tidak menular (non communicable diseases), penyakit kronik dan degeneratif. Lanjut usia mengacu pada konsep active ageing dari World Health Organization, yaitu proses menua terpenuhi kesejahteraan sosialnya, sehingga kesehatan fisik, mental dan sosial terpelihara baik dan dapat tetap sejahtera sepanjang hidup dan tetap produktif dalam rangka meningkatkan kualitas hidup sebagai anggota masyarat. Peran serta lembaga pemerintah dan swasta, masyarakat, keluarga dan tenaga kesehatan diperlukan dalam melayani kebutuhan penduduk lansia. Upaya promotif dan preventif merupakan faktor penting dalam mengurangi angka kesakitan. Upaya yang dikembangkan pemerintah adalah meningkatkan pelayanan kesehatan dasar bagi lanjut usia di pelayanan kesehatan dasar, meningkatkan upaya rujukan kesehatan bagi lanjut usia dan menyediakan sarana prasarana yang ramah bagi lansia. Jurnal Berkala Ilmiah Kedokteran Duta Wacana menerbitkan artikel-artikel karya ilmiah kesehatan dan masalah-masalah kesehatan lansia, diharapkan melalui publikasi tersebut pengenalan dan pembelajaran terhadap kesehatan dan masalah-masalah kesehatan lansia semakin baik. ${ }^{1,2}$

Jurnal Berkala Ilmiah Kedokteran Duta Wacana (BIKDW) Volume 3 Nomor 2, menerbitkan artikel hasil penelitian tentang masalah-masalah kesehatan lansia. Amadea Rigenastiti melakukan penelitian observasional analitik menggunakan desain potong lintang untuk meneliti hubungan antara visus dengan risiko jatuh pada 97 lansia di Kelurahan Baciro Yogyakarta, mengekslusikan lansia buta huruf dan yang memiliki keterbatasan neuromotorik ekstremitas bawah. Data visus lansia didapatkan melalui pemeriksaaan visus menggunakan kartu Snellen, data risiko jatuh didapat dari kuesioner Falls Efficacy Scale International (FES-I). Hasil analisis korelasi Spearman pada visus terbaik dan risiko jatuh yaitu $\mathrm{r}=0.190$ dan $\mathrm{p}=0.063(\mathrm{p}>0.05)$, sedangkan visus terburuk dan risiko jatuh yaitu $\mathrm{r}=0.240$ dan $\mathrm{p}=0.018(\mathrm{p}<0.05)$. Kesimpulan penelitian ini adalah semakin buruk visus seorang lansia akan semakin tinggi risiko jatuhnya.

Pendekatan holistik pada lansia, ada di dalam ilmu gerontologi dan ilmu geriatri. Gerontologi adalah ilmu yang mempelajari proses penuaan dari tinjauan biologis, psikologis, sosial dan spiritul. Geriatri adalah cabang ilmu kedokteran spesialisasi penyakit dalam, mempelajari tatalaksana dari multi-patologi 
penyakit-penyakit tidak menular, kronik dan degeneratif pada lansia. Gerontologi menekankan aspek preventif sedangkan geriatri menekankan aspek kuratif penyakit multi patologi seorang individu sejak mencapai usia 60 tahun. Upaya preventif melalui perilaku hidup sehat sepanjang masa, meliputi penilaian status gizi, memperhatikan pola makan lansia, pola tidur, dan olahraga. Populasi penduduk Indonesia di atas umur 50 tahun, berdasarkan penelitian dengan menggunakan kuesioner EQ-5D-5L dan WHOQOL-BREF, pada 1056 orang rentang umur 17-75 tahun dalam populasi umum di Indonesia, melaporkan dirinya lebih banyak mengalami penurunan kualitas dalam mobilitas, perawatan diri, aktivitas hidup sehari-hari dan nyeri/ ketidak nyamanan dibandingkan populasi usia muda. Semakin tua umur responden menjukkan semakin rendah kualitas hidupnya dan semakin tidak merasa puas terhadap kesehatan pribadinya. Penelitian pada penduduk diatas umum 50 tahun kabupaten Purworejo Jawa Tengah Indonesia, menggunakan kuesioner INDEPTH WHOSAGE yang diringkas dan dimodifikasi dan diterbitkan dalam Global Health Action Supplement di tahun 2010, menyimpulkan lansia berjenis kelamin perempuan, tidak menikah dan level pendidikan dan sosial ekonomi rendah menunjukkan penilaian diri terhadap kualitas hidup yang rendah. Pelayanan lansia di posyandu lansia dapat meningkatkan pelayanan kesehatan lansia yang sakit maupun mempromosikan kesehatan lansia sehat. $3,4,5$

Kesimpulan dari editorial ini adalah adanya pergeseran demografi usia karena peningkatan penduduk lanjut usia, menjadi perhatian khusus dan membutuhkan peran serta lembaga pemerintah dan swasta, masyarakat, keluarga dan tenaga kesehatan untuk melakukan peningkatan pelayanan kesehatan preventif, promotif dan kuratif terhadap lansia yang rentan mengalami multimorbidity yang diketahui didasari oleh proses multi patologi.

\section{DAFTAR PUSTAKA}

1. Undang-Undang Republik Indonesia No. 13 tahun 1998 tentang Kesejahteraan Lanjut Usia.

2. Kementrian kesehatan RI. 2015. PELAYANAN DAN PENINGKATAN KESEHATAN USIA LANJUT. http://www.depkes.go.id/article/print/ 15052700010/ pelayanan-dan-peningkatan-kesehatan-usia-lanjut. html. Diakses tanggal 25 Juli 2018.

3. Abikusno N. 2013. Kelanjutusiaan Sehat Menuju Masyarakat Sehat untuk Segala Usia. Buletin Jendela Data \&amp; Informasi Kesehatan, semester I; 2528.

4. Purba FD, Hunfeld JA, Iskandarsyah A, Fitriana TS, Sadarjoen SS, Passchier J, Busschbach JJV. 2018. Quality of life of the Indonesian general population: Test-retest reliability and population norms of the EQ-5D-5L and WHOQOLBREF. PloS ONE 13(5): e0197098.

5. Ng N, Hakimi M, Byass P, Wilopo S, Wall S. 2010. Health and quality among older rural people in Purworejo District, inonesia. Global Health Action Supplement 2: 78-87. 